\title{
IMPLEMENTASI METODE PROBLEM SOLVING DALAM MENINGKATKAN PEMBELAJARAN PENDIDIKAN AGAMA KRISTEN DI SEKOLAH
}

\author{
Nova Ritonga ${ }^{1}$, Juliandes Leonardo Trisno Mone ${ }^{2}$, Mathan Yunip ${ }^{3}$, \\ Yunardi Kristian Zega ${ }^{4}$ \\ Sekolah Tinggi Teologi Mawar Saron Lampung ${ }^{1,2,3}$ \\ Universitas Kristen Indonesia ${ }^{4}$ \\ novaritonga9@gmail.com ${ }^{1}$,juliandes1997@gmail.com², m-yunip@yahoo.com³ \\ yunardichristian@gmail.com ${ }^{4}$
}

\begin{abstract}
Abstrak
Pembelajaran masa kini adalah model pembelajaran yang berpusat pada peserta didik (student center learning). Dalam pembelajaran ini, guru perlu menggunakan berbagai metode pembelajaran yang dapat melibatkan peserta didik secara langsung. Sistem pembelajaran seperti ini sesuai dengan standar pendidikan dan kurikulum tahun 2013. Walaupun kurikulum tahun 2013 sudah menerapkan pembelajaran yang berpusat pada peserta didik, namun hingga saat ini masih ditemukan guru-guru termasuk guru pendidikan agama Kristen yang masih mempergunakan metode konvensional (ceramah) yang menyebabkan proses pembelajaran menjadi kurang menarik dan membosankan. Oleh karena itulah dibutuhkan suatu terobosan yang dapat meningkatkan pembelajaran pendidikan agama Kristen di sekolah. Dengan demikian, tujuan penelitian ini adalah untuk memaparkan implementasi metode problem solving dalam meningkatkan proses pembelajaran pendidikan agama Kristen di sekolah. Metode yang dipergunakan dalam penelitian ini adalah studi kepustakaan dengan kajian literatur yang menggunakan buku, jurnal, kamus, dan sumber-sumber lainnya untuk memaparkan implementasi metode problem solving dalam pembelajaran pendidikan agama Kristen. Adapun hasil penelitian ini yaitu implementasi metode problem solving dapat meningkatkan pembelajaran pendidikan agama Kristen di sekolah karena peserta didik dituntut terlibat secara aktif dalam proses pembelajaran.
\end{abstract}

Kata kunci : Metode, Pembelajaran, Pendidikan Agama Kristen, Sekolah

\begin{abstract}
Today's learning has used a student-centered learning model. In this learning, the teacher uses various learning methods which are certainly more interesting and involve students directly. This learning system is in accordance with the education standards and curriculum in 2013. Although the 2013 curriculum has implemented student-centered learning, until now there are still teachers including Christian religious education teachers who still use conventional methods (lectures) which cause the learning process is less interesting and tedious. Therefore, a breakthrough is needed that can improve Christian religious education learning in schools. Thus, the purpose of this study is to describe the implementation of problem solving methods in improving the learning process of Christian religious education in schools. The method used in
\end{abstract}


this research is literature study with literature review using books, journals, dictionaries, and other sources to describe the implementation of problem solving methods in Christian religious education learning. The result of this research is that the implementation of problem solving methods can improve Christian religious education learning in schools because students are actively involved in the learning process.

Keywords: Methods, Learning, Christian Religious Education, School

\section{Pendahuluan}

Di Indonesia banyak sekolah yang masih hanya berfokus dengan penggunaan metode pembelajaran konvensional. Metode pembelajaran konvensional masih sering digunakan dalam berbagai pembelajaran di setiap jenjang pendidikan baik, SD, SMP, SMA maupun di Perguruan Tinggi. Ada berbagai faktor yang memaksa para pendidik untuk menggunakan metode konvensional, antara lain: 1) Tuntutan sistem yang di mana membuat para pendidik dituntut agar dapat menyelesaikan materi pelajaran dengan waktu yang terbatas, dan 2) Karena para pendidik dan siswa masih belum terbiasa dengan metode pembelajaran kekinian. Kedua faktor ini merupakan penyebab masih seringnya metode pembelajaran konvensional digunakan dalam pendidikan di Indonesia. Oleh karena itu, semua pihak yang terlibat dalam dunia pendidikan perlu menyadari dua faktor tersebut, sehingga bisa mencari solusi yang tepat untuk menyelesaikannya. ${ }^{1}$

Selain itu, faktor lain yang membuat guru lebih suka menggunakan metode konvensional karena guru juga kurang memiliki kemampuan dalam merancang pembelajaran yang kreatif dan

\footnotetext{
1 Abdul Latip, "Saatnya Tinggalkan Metode Pembelajaran Konvensional," Kompasiana, last modified 2018, diakses Maret 12, 2021, https://www.kompasiana.com/altip/5c0db2cbab12 ae71c8361e04/saatnya-tinggalkan-metodepembelajaran-konvensional.
}

inovatif dengan menggunakan metode yang lain. Hal ini ditunjukkan dengan adanya keluhan dari para guru yang mengalami kesulitan dalam merancang pembelajaran yang baik dan guru belum mengenal berbagai metode pembelajaran. $^{2}$

Pendidikan merupakan salah satu bagian yang tidak dapat lepas dari kehidupan manusia, karena mampu mempengaruhi kualitas hidup seseorang. Hamid Darmadi, Sulha, dan Ahmad Jamalong, mengutip pernyataan Nelson Mandela yang menyatakan, Education is most powerfull weapon, we can use to change the world (pendidikan adalah senjata paling ampuh yang bisa digunakan untuk mengubah dunia). ${ }^{3}$ Setiap orang perlu untuk menempuh pendidikan agar mampu mengikuti perkembangan zaman yang semakin maju dan berkembang.

Perkembangan zaman berkaitan erat dengan perkembangan pendidikan. Keduanya saling berhubungan, artinya perkembangan zaman tidak lepas dari perkembangan dan kemajuan pendidikan di mana pendidikan memberi sumbangsih terhadap kemajuan zaman. Selain itu,

\footnotetext{
2 Fauzatul Ma'rufah Rohmanurmeta, Arni Gemilang Harsanti, dan Heny Kusuma Widyaningrum, "Pengaruh Metode Brainstorming terhadap Motivasi dan Hasil Belajar pada Pembelajaran Tematik Integratif," Jurnal Dimensi Pendidikan dan Pembelajaran 4, no. 2 (2016): 10-19.

${ }^{3}$ Hamid Darmadi, Sulha, dan Ahmad Jamalong, Pengantar Pendidikan (Bandung: Alfabeta, 2018), 1 .
} 
kemajuan zaman juga ditandai dengan berkembangnya teknologi yang mempengaruhi dunia pendidikan. Oleh karena itu, dunia pendidikan dituntut untuk mampu menghasilkan orang-orang yang berkompeten dan mampu mengatasi segala permasalahan yang mereka hadapi ke depannya. Untuk menghasilkan orangorang yang handal dan siap menghadapi tantangan kehidupan di tengah masyarakat maka dibutuhkan berbagai strategi yang nantinya dapat meningkatkan proses pembelajaran dalam dunia pendidikan. Untuk itu, guru perlu memahami berbagai strategi dan dapat menyesuaikan strategi dan metode yang dipergunakan dalam proses pembelajaran yang sesuai dengan tuntutan pendidikan masa kini. ${ }^{4}$

Lembaga pendidikan di Indonesia selalu berusaha mengembangkan struktur kurikulum, sistem pendidikan, dan strategi pembelajaran dalam rangka meningkatkan mutu pendidikan. Meningkatnya mutu pendidikan di sekolah sangat dipengaruhi oleh kemampuan para pendidik dalam mengimplementasikan berbagai metode pembelajaran. Salah satu metode yang cukup relevan untuk diterapkan ke dalam proses pembelajaran masa kini adalah metode problem solving, yaitu metode yang dapat melatih peserta didik dalam memecahkan permasalahan. ${ }^{5}$

\footnotetext{
4 Desi Sianipar et al., "Pelatihan Penggunaan Metode Mengajar Remaja di Masa Pandemi Covid-19 di HKBP Resort Jatisampurna Bekasi," JURNAL ComunitÃ Servizio: Jurnal Terkait Kegiatan Pengabdian kepada Masyarakat, terkhusus bidang Teknologi, Kewirausahaan dan Sosial Kemasyarakatan 2, no. 2 (2020): 406-428.

5 Desi Sianipar et al., "Pelatihan Penyusunan Kurikulum Pendidikan Agama Kristen Remaja di HKBP Jatisampurna Bekasi," JURNAL Comunit $\tilde{A}$ Servizio: Jurnal Terkait Kegiatan Pengabdian kepada Masyarakat, terkhusus bidang Teknologi, Kewirausahaan dan Sosial Kemasyarakatan 2, no. 2 (2020): 447-457.
}

Thomas Edison mengatakan bahwa, metode problem solving bertujuan membangkitkan peserta didik agar berpikir dengan menggunakan pengetahuannya. $^{6}$ Abdul Majid juga mengatakan bahwa, metode problem solving merupakan metode yang berpusat pada pemecahan suatu masalah dengan mengoptimalkan kemampuan berpikir. ${ }^{7}$ Nana Syaodih Sukmadinata dan Erliana Syaodih mengatakan bahwa, metode problem solving menjadi salah satu metode yang dapat mengembangkan cara berpikir tahap tinggi dalam memecahkan masalah. ${ }^{8}$ Jadi dapat disimpulkan bahwa, metode problem solving merupakan metode yang betujuan merangsang peserta didik agar berpikir memecahkan atau menyelesaikan sebuah masalah dengan tepat dan bertanggungjawab.

Penerapan metode problem solving sudah sering diterapkan pada mata pelajaran umum seperti mata pelajaran Matematika, IPS, dan Budi Pekerti. Dari beberapa penelitian tersebut ditemukan bahwa, penerapan metode problem solving dapat meningkatkan kreatifitas proses pembelajaran dengan lebih maksimal. ${ }^{9}$ M. Reyhan Florean mengatakan bahwa, metode problem solving dapat meningkatkan aktivitas belajar dan hasil belajar peserta didik dengan lebih maksimal dibandingkan

\footnotetext{
${ }^{6}$ Thomas Edison, 52 Metode Mengajar (Bandung: Kalam Hidup, 2017), 80-81.

7 Abdul Majid, Strategi Pembelajaran (Bandung: Remaja Rosdakarya, 2013), 212.

${ }^{8}$ Nana Syaodin Sukmadinata dan Erliana Syaodin, Kurikulum dan Pembelajaran Kompetensi (Bandung: Refika Aditama, 2014), 175.

${ }^{9}$ Ii Wartini, Hilman Mangkuwibawa, dan Cecep Anwar, "Penerapan Metode Problem Solving Untuk Meningkatkan Pemahaman Matematika," al-Aulad: Journal of Islamic Primary Education 1, no. 2 (November 6, 2018), http://journal.uinsgd.ac.id/index.php/alaulad/article/view/3519.
} 
dengan penggunaan metode konvensial. ${ }^{10}$ Tatag Setyawan juga mengatakan bahwa, penerapan metode problem solving dapat meningkatkan antusiasme yang tinggi terhadap peserta didik dalam mengikuti pembelajaran, sehingga menghasilkan peserta didik yang memiliki kemampuan berpikir ilmiah dan terstruktur. ${ }^{11}$ Jadi dapat disimpulkan bahwa, dengan adanya penggunaan metode problem solving dalam proses pembelajaran di sekolah, diharapkan dapat menolong guru-guru, khususnya guru PAK dalam meningkatkan pengetahuan, spiritualitas, sikap, dan karakter dari setiap peserta didik yang diajar. Selain itu, dengan penerapan metode problem solving, diharapkan peserta didik memiliki kemampuan berfikir kritis dan inovatif, dalam menyelesaikan berbagai permasalahan yang mereka temui.

\section{Metode}

Dalam artikel ini, penulis menggunakan metode penelitian kualitatif dengan kajian pustaka (library research), yaitu dengan memanfaatkan sumbersumber pustaka seperti buku, jurnal, internet, dan sumber lainnya untuk mengkaji topik yang dibahas. Studi pustaka atau kepustakaan merupakan serangkaian kegiatan penelitian di mana data-data diperoleh melalui data pustaka

\footnotetext{
${ }^{10}$ M. Reyhan Floren, "Penerapan Metode Problem Solving Untuk Meningkatkan Hasil Belajar Siswa dalam Pembelajaran IPS di Kelas IV SDN Pojok 03 Kabupaten Tulungagung," PENA SD (Jurnal Pendidikan dan Pembelajaran Anak Sekolah Dasar) 2, no. 1 (2016): 9-22.

11 Tatag Setyawan, "Meningkatkan Prestasi Belajar Pendidikan Agama Kristen dalam Materi Menjaga dan Memelihara Alam dengan Menggunakan Model Pembelajaran Problem Solving di SMP Negeri 1 Rantau Pulung," Jurnal Ilmu Pendidikan LPMP Kalimantan Timur 11, no. 2 (2017): 23-32.
}

dan bukan data lapangan. ${ }^{12}$ Data yang diperoleh baik melalui buku, jurnal, internet diolah dengan memilih data-data yang relevan dengan kajian yang di bahas.

\section{Hasil dan Pembahasan}

\section{A. Pengertian Metode Problem Solving}

Metode problem solving adalah sebuah metode pembelajaran yang menitikberatkan pada pemahaman, solusi, identifikasi kekeliruan, mencari alternatif, dan menyusun pertanyaan. Penerapan metode ini merupakan kegiatan pembelajaran dengan cara melatih peserta didik dengan memperhadapkan mereka dengan berbagai masalah, kemudian dipecahkan atau diselesaikan sendiri maupun berkelompok. Pokok utama pembelajarannya pada penggalian dan penemuan yang berdasar pada pemecahan masalah. $^{13}$

Metode problem solving dapat dipahami lebih jelas dengan memperhatikan ciri-cirinya, antara lain: Pertama, dalam penerapan metode problem solving, peserta didik diharuskan melakukan beberapa kegiatan. Dalam metode problem solving peserta didik tidak hanya sekedar mendengar, menulis. Namun, melalui metode ini siswa dituntut lebih berpikir kritis, aktif, adanya komunikasi, mencari, dan mengolah setiap data yang didapat, sampai pada tahap menyimpulkan. Kedua, sesuai dengan namanya, metode problem solving menggunakan masalah sebagai indikator utama dari proses pembelajaran. Artinya,

\footnotetext{
12 Supriyadi Supriyadi, "Community of Practitioners: Solusi Alternatif Berbagi Pengetahuan antar Pustakawan," Lentera Pustaka: Jurnal Kajian Ilmu Perpustakaan, Informasi dan Kearsipan 2, no. 2 (Februari 23, 2017): 83, https://ejournal.undip.ac.id/index.php/lpustaka/arti cle/view/13476.

${ }^{13}$ Gustaf Asyirint, Langkah Cerdas Menjadi Guru sejati Berprestasi (Yogyakarta: Bahtera Buku, 2010),69.
} 
proses pembelajaran akan dapat dilakukan jika ada masalah yang perlu diselesaiakan. Jika tidak, maka pembelajaran tidak dapat dilakukan dengan menggunakan metode ini. Ketiga, berpikir menggunakan metode ilmiah dengan proses berpikir deduktif dan induktif. Proses berpikir ini dilakukan secara sistematis dan empiris. Sistematis artinya berpikir ilmiah, sedangkan empiris artinya proses penyelesaian masalah yang didasarkan pada data dan fakta. ${ }^{14}$ Oleh karena itu, dalam menyimpulkan suatu permasalahan dengan menggunakan metode problem solving memerlukan data dan fakta yang akurat.

Pada dasarnya metode problem solving didasarkan pada beberapa teori berikut:

1. Teori perkembangan Progresivisme. Menurut teori ini, pengetahuan yang benar pada masa kini mungkin tidak benar pada masa yang akan datang. Untuk itu, pendidikan perlu berpusat pada anak, bukan berfokus pada guru. Junihot Simanjuntak menyatakan, progresivisme merupakan pendidikan yang berpusat pada siswa dan memberi penekanan lebih pada kreativitas, aktivitas belajar, hasil belajar "dunia nyata", dan juga pengalaman teman sebaya. ${ }^{15}$

2. Teori perkembangan Pragmatisme. Teori ini menyatakan bahwa tujuan pendidikan untuk memampukan peserta didik dapat hidup di tengahtengah masyarakat yang heterogen. Dengan demikian, guru berperan sebagai rekan dialog peserta didik menghadapi kenyataan hidup, metode dan kompetensi pemecahan masalah

14 Wina Sanjaya, Staretegi Pembelajaran Berorientasi Standar Proses Pendidikan (Jakarta: Kencana, 2013).

15 Junihot Simanjuntak, Filsafat Pendidikan dan Pendidikan Kristen (Yogyakarta: ANDI, 2017), 31, 50-51. dan partisipasif diutamakan, hal yang ditekankan adalah prosesnya bukan isi dan keberhasilan dilihat dari penilaian sosial. $^{16}$

3. Teori Konstruktivisme. Teori ini menyatakan bahwa, peserta didik membangun pengetahuan secara berkala melalui interaksi sosial. Pada saat pembelajaran dimulai, peserta didik sudah memiliki pengetahuan tertentu. Kemudian, dalam proses pembelajaran, pemahaman dan pengetahuan tersebut terjadi proses konstruksi, peserta didik merevisi dan memodifikasi pengetahuan yang pada akhirnya terbentuk pengetahuan yang baru. Dengan demikian, menurut teori ini, pengetahuan dibangun oleh peserta didik melalui keaktifannya sendiri. $^{17}$

Jadi, dapat disimpulkan teori-teori di atas sangat berkontribusi bagi pelaksanaan metode problem solving di sekolah. Dalam perkembangannya metode problem solving semakin menyebar ke berbagai negara karna dianggap mampu untuk menyelesaikan masalah-masalah yang ada. Kong $\mathrm{Hu} \mathrm{Cu}$ atau Konfusius (551 SM - 479 SM) filsuf Cina, menyatakan bahwa, "yang saya dengar, saya lupa. Yang saya lihat, saya ingat. Yang saya kerjakan, saya pahami." ${ }^{18}$ Siberman dalam Suryo Hartanto juga menegaskan bahwa, keikutsertaan peserta didik melalui tindakan langsung dalam proses pembelajaran seperti mendengar dan melihat, mengajukan pertanyaan, dan diskusi akan membuat peserta didik lebih

\footnotetext{
16 Simanjuntak, Filsafat Pendidikan dan Pendidikan Kristen, 50-51.

17 Ridwan abdullah Sani, Inovasi Pembelajaran (Jakarta: Bumi Aksara, 2009), 11-12.

18 Alamsyah Said dan Andi Budimanjaya, 95 Strategi Mengajar Multiple Intellegences (Jakarta: Kencana, 2015), 32.
} 
memahami dan lebih menguasai ilmu yang dipelajarinya. ${ }^{19}$ Dari pernyataan ini, dapat dilihat bahwa, peserta didik akan lebih menguasai suatu meteri jika mereka memiliki pengalaman terhadap materi secara langsung dan terlibat di dalamnya.

\section{B. Kelebihan dan Kekurangan Metode Problem Solving}

Metode Problem Solving memiliki beberapa kelebihan: ${ }^{20}$

1. Menjadikan pendidikan di sekolah relevan dengan kehidupan.

2. Melatih peserta didik agar trampil mengidentifikasi dan menyelesaikan masalah.

3. Membangkitkan kemampuan dan kreativitas berpikir dari para peserta didik.

Selain memiliki kelebihan, metode Problem Solving juga memiliki kekurangan, antara lain: ${ }^{21}$

1. Masalah yang dipecahkan harus disesuaikan dengan tingkat kesulitan dan kemampuan berpikir dari setiap peserta didik, jenjang sekolah, serta pengetahuan dan pengalaman yang telah dimiliki peserta didik. Dalam menentukan tingkat kesulitan masalah yang akan dipecahkan oleh peserta didik, sangat memerlukan keterampilan dari seorang guru.

2. Di dalam proses pembelajaran dengan menggunakan metode problem solving memerlukan waktu yang cukup lama.

3. Metode problem solving dapat mengubah kebiasaan peserta didik

19 Suryo Hartanto, Mobalean Meaning (Model Pembelajaran Berbasis Lean Manufacturing) (Yogyakarta: Deepublish, 2020), 16.

${ }^{20}$ Syaiful Bhri dan Aswan Zain, Strategi Belajar Mengajar (Jakarta: Rineka Cipta, 2002), 104-105.

${ }^{21}$ Syaiful Bhri dan Aswan Zain, Strategi Belajar Mengajar (Jakarta: Rineka Cipta, 2002), 104-105. yang belajar hanya untuk mendengarkan informasi dari guru, menjadi belajar dengan berpikir memecahkan suatu masalah sendiri atau kelompok. Hal ini tentu akan memerlukan berbagai sumber belajar yang lebih banyak, sehingga menjadi suatu kesulitan tersendiri.

Berdasarkan pemaparan di atas dapat disimpulkan bahwa, metode problem solving dapat membiasakan peserta didik untuk berpikir kritis dalam pemecahan masalah. Untuk itu, dalam penerapannya metode ini perlu disesuaikan dengan tingkatan usia dan kemampuan dari peserta didik yang diajar.

\section{Langkah-Langkah Pengimplementasian Metode Problem Solving}

Metode problem solving merupakan suatu metode berpikir. Dalam penerapannya, metode ini dapat dikombinasikan dengan metode-metode lainnya seperti diskusi, dari pembuktian yang dimulai dengan mencari data sampai kepada menarik simpulan akhir. Adapun langkah-langkah yang perlu diperhatikan dalam menerapkan metode problem solving, antara lain: ${ }^{22}$

1. Memiliki suatu masalah yang jelas untuk dipecahkan. Dengan demikian, masalah yang diberikan oleh guru harus disesuai dengan tingkat kemampuan peserta didik.

2. Membutuhkan data yang akurat dan keterangan yang dapat digunakan untuk memecahkan masalah.

3. Merumuskan jawaban sementara dari masalah tersebut. Jawaban sementara didasarkan pada data yang diperoleh.

\footnotetext{
22 Nana Sudjana, Dasar-dasar Proses Belajar Mengajar (Bandung: Sinar Baru Algensindo, 2009), 85-86.
} 
4. Menguji kebenaran dari jawaban sementara tersebut. Tujuannya agar peserta didik bertanggung jawab ketika memecahkan suatu masalah. Oleh karena itu, untuk menguji kebenaran jawaban diperlukan metode-metode lainnya, seperti demostrasi, diskusi, dan observasi.

5. Membuat kesimpulan yang akurat. Artinya, peserta didik membuat kesimpulan akhir untuk memecahkan masalah.

Untuk mengimplementasikan metode problem solving dalam pembelajaran PAK, guru pertama-tama harus dapat mengidentifikasi materi pelajaran dan memilih materi yang sesuai dengan menggunakan metode problem solving. Selanjutnya, guru PAK menetapkan materi yang tepat dengan membuat masalah yang harus dipecahkan oleh peserta didik. Selain dari buku teks yang tersedia, guru PAK juga dapat mengambil masalah-masalah yang akan dipecahkan dari sumber-sumber lain. Misalnya dari peristiwa yang terjadi di lingkungan sekitar, peristiwa dalam keluarga atau dari peristiwa kemasyarakatan. $^{23}$ Selain itu, dalam pemecahan masalah yang dikerjakan peserta didik, guru berkewajiban untuk mendampingi dan mengarahkan peserta didik agar dapat memecahkan masalahnya secara sistematis.

Newell dan Simon dalam Herry Agus Susanto menyatakan bahwa, dalam pemecahan masalah, seseorang memerlukan tiga tahapan: 1) orientasi masalah, berkaitan dengan pemahaman awal yaitu apa yang dipahami, apa yang diberikan, apa masalahnya, dan apakah sebelumnya ada masalah yang sama dengan itu; 2) melaksanakan pemecahan masalah, dilakukan sesuai dengan prosedur; 3) mengevaluasi hasil

23 Nana Sudjana, Dasar-dasar Proses Belajar Mengajar, 215. penyelesaian masalah dengan memastikan apakah hasil yang sudah dirumuskan benar-benar sesuai dengan jawaban masalah yang dibutuhkan. ${ }^{24}$ Herry Agus Susanto mengutip perdapat Hayes yang mengklasifikasikan enam tahapan dalam melakukan pemecahan masalah, yaitu: 1) mengidentifikasi masalah atau identifying the problem, 2) gambaran dari masalah atau representation of the problem, 3) perencanaan solusi atau planning the solution, 4) pelaksanaan rencana atau execute the plan, 5) mengevaluasi rencana atau evaluate the plan, 6) evaluasi solusi atau evaluate the solution. ${ }^{25}$

Menurut Mulyasa, ada empat karakteristik pembelajaran metode problem solving, sebagai berikut: ${ }^{26}$

1. Konsep Dasar (Basic Concept). Guru berperan sebagai fasilitator harus memberikan petunjuk, referensi atau contoh serta skill yang diperlukan dalam pembelajaran tersebut. Pemberian petunjuk, referensi atau contoh serta skill ini bermaksud agar peserta didik mendapatkan gambaran tentang masalah yang akan diselesaikan.

2. Pendefenisian Masalah (Defening the Problem). Guru yang berperan sebagai fasilitator harus menyampaikan skenario permasalahan serta tahapantahapan yang harus dilakukan dalam memecahkan masalah kepada peserta didik.

3. Pembelajaran Mandiri (Self Learning). Setelah peserta didik telah mengetahui apa yang harus mereka lakukan maka peserta didik perlu mencari berbagai sumber yang dapat memperjelas masalah yang akan diselesaikan.

\footnotetext{
${ }^{24}$ Herry Agus Susanto, Pemahaman Pemecahan Masalah Berdasarkan Gaya Kognitif (Yogyakarta: Deepublish, 2015), 19-10.

${ }^{25}$ Susanto, 20.

26 E. Mulyasa, Strategi Pembelajaran PAUD (Bandung: Remaja Rosdakarya, 2017), 165-167.
} 
4. Pertukaran Pengetahuan (Exchange Knowledge). Setelah peserta didik mendapat informasi tentang permasalahan yang akan diselesaikan dari berbagai sumber yang tersedia, peserta didik diarahkan untuk berdiskusi dalam kelompok dan dibantu oleh guru dalam rangka mengklarifikasi setiap informasi yang telah diperoleh.

\section{Implementasi Metode Problem Solving dalam Pembelajaran Pendidikan Agama Kristen di Sekolah}

Pembelajaran Pendidikan Agama Kristen (PAK) akan mencapai tujuannya, jika guru PAK memiliki kemampuan dalam menerapkan berbagai metode pembelajaran yang dapat membuat peserta didik antusias mengikuti pembelajaran. Jika adanya antusias yang tinggi dari peserta didik, maka pembelajaran PAK akan menjadi pembelajaran yang menarik dan menyenangkan. Salah satu metode yang dapat digunakan oleh guru PAK demi menghindari kebosanan peserta didik tersebut yaitu dengan menggunakan metode problem solving.

Adapun beberapa tahapan yang perlu diperhatikan dalam menerapkan metode problem solving, sebagai berikut: ${ }^{27}$

1. Tahap Persiapan

- Guru menetapkan tujuan dan topik pelajaran.

- Guru mempersiapkan materi pelajaran yang sesuai dengan tujuan dan topik pelajaran.

27 Indah Khairani dan Rini Safitri, "Penerapan Metode Pembelajaran Problem Solving Untuk Meningkatkan Hasil Belajar Peserta Didik Pada Materi Usaha Dan Energi di MAN RUKOH Banda Aceh," Jurnal Pendidikan Sains Indonesia 5, no. 2 (Februari 2, 2018): 32-41, http://jurnal.unsyiah.ac.id/JPSI/article/view/9814.
- Guru mencari dan menentukan masalah yang ingin diselesaikan oleh peserta didik, yaitu masalah yang berkaitan dengan materi pelajaran.

- Guru mempersiapkan media pembelajaran yang akan dipakai pada proses belajar-mengajar. Misalnya laptop, LCD, speaker, dan lainnya.

2. Tahap Pelaksanaan

- Kegiatan Awal. Kegiatan ini dimulai dengan menyapa peserta didik dan mengawalinya dengan doa pembukaan. Kemudian, guru memeriksa kehadiran peserta didik. Kegiatan awal dilakukan agar guru mengetahui kesiapan dari setiap peserta didik dalam mengikuti pembelajaran.

- Kegiatan Inti. Kegiatan ini dimulai dari guru yang menjelaskan topik pembelajaran. Penjelasan dapat dilakukan dengan memberi beberapa pertanyaan yang dapat menarik perhatian peserta didik sehingga membawa pemikiran mereka ke arah materi pelajaran yang ingin dipelajari. Selanjutnya, guru menyampaikan permasalahan apa yang akan dipecahkan oleh peserta didik. Dalam hal ini, guru dapat membagi peserta didik dalam beberapa kelompok kecil (3-4 orang) disesuaikan dengan jumlah peserta didik. Setelah kelompok terbentuk, guru menyampaikan aturan-aturan apa saja yang wajib ditaati oleh semua anggota kelompok selama kegiatan berlangsung. Selanjutnya, guru memberi petunjuk dan tahapantahapan apa saja yang dapat dilakukan peserta didik dalam memecahkan masalah yang telah diberikan.

- Kegiatan Penutup. Dalam tahap ini guru harus menyimpulkan dan menyampaikan refleksi mengenai 
materi yang telah dipelajari pada hari tersebut.

\section{Tahap Evaluasi}

Salah satu bagian penting dalam pengimplementasian metode problem solving adalah melakukan tahap evaluasi. Untuk itu, setiap guru perlu melakukan evaluasi agar dapat mengidentifikasi setiap tahapan-tahapan dalam proses pembelajaran sehingga ke depannya dapat diperbaiki atau pun lebih dioptimalkan pada pertemuan berikutnya.

Selanjutnya, guru juga perlu untuk membandingkan pencapaian keberhasilan peserta didik di setiap pertemuan. Dengan demikian, dalam penggunaan metode problem solving guru harus sekreatif mungkin dalam melaksanakan proses pembelajaran dengan berbagai masalah yang menarik dan sesuai dengan kebutuhan dari peserta didik. Untuk itu, Adapun contoh gambaran kegiatan dalam pembelajaran PAK yang dapat dilaksanakan oleh guru PAK dengan menggunakan metode problem solving untuk anak kelas VIII (delapan) Sekolah Menengah Pertama (SMP), sebagai berikut:

\begin{tabular}{|c|c|c|c|}
\hline No & Tema & Masalah & Kegiatan (Penuntun) \\
\hline 1 & $\begin{array}{l}\text { Siapakah } \\
\text { Sesamaku } \\
\text { (Luk. 10:29- } \\
\text { 37) }\end{array}$ & $\begin{array}{l}\text { Masalah disajikan dalam } \\
\text { bentuk video singkat } \\
\text { tentang seseorang yang } \\
\text { berjalan dari Yerusalem } \\
\text { ke Yerikho, dia dihadang } \\
\text { perampok dan dirampas } \\
\text { hartanya. Kemudian dia } \\
\text { dianiaya perampok } \\
\text { sampai hampir mati. } \\
\text { Kemudian, seorang } \\
\text { imam berjalan melalui } \\
\text { jalan itu dan melihat } \\
\text { orang yang dirampok } \\
\text { tersebut, tetapi dia tidak } \\
\text { mau menolong. } \\
\text { Demikian juga dengan } \\
\text { orang Lewi tidak juga } \\
\text { mau menolong. } \\
\text { Kemudian datang } \\
\text { seorang Samaria yang } \\
\text { menolong orang tersebut, } \\
\text { dengan membiayai } \\
\text { pengobatan dan } \\
\text { perawatannya. Orang } \\
\text { yang dirampok adalah } \\
\text { orang Yahudi. Orang } \\
\text { Yahudi tidak bersahabat } \\
\text { dengan orang Samaria } \\
\text { karena orang Yahudi } \\
\text { menganggap orang }\end{array}$ & 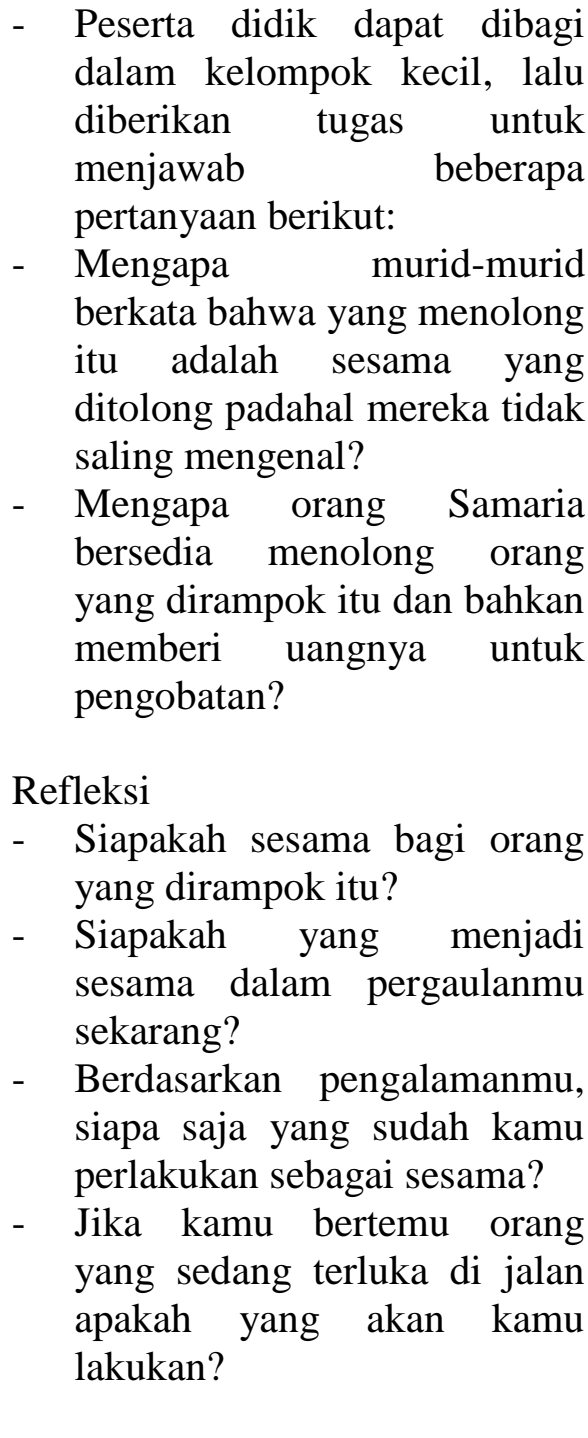 \\
\hline
\end{tabular}




\begin{tabular}{|c|c|c|c|}
\hline & & Samaria adalah kafir. & \\
\hline 2 & $\begin{array}{l}\text { Akibat } \\
\text { Kenakalanku } \\
\text { (1 Sam. 11:1- } \\
\text { 27; Kis. 5:1- } \\
\text { 11) }\end{array}$ & 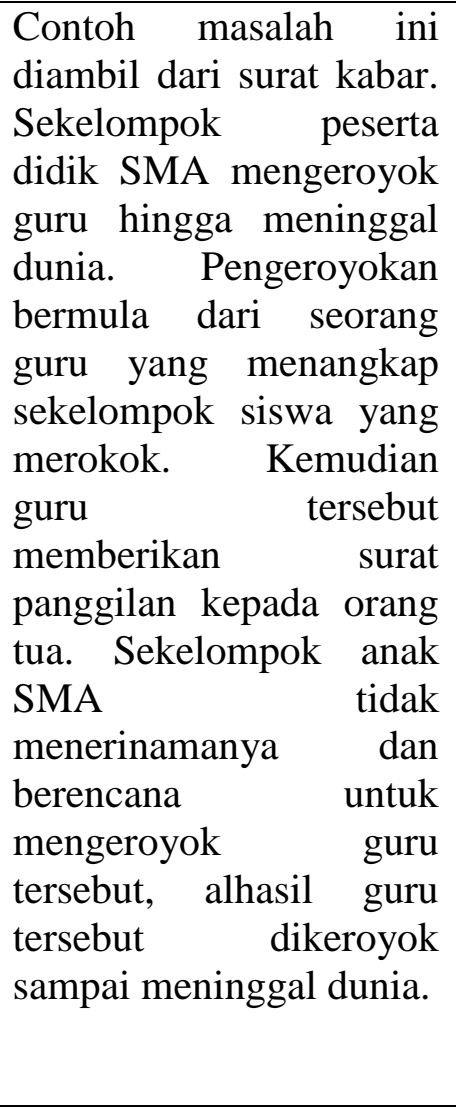 & 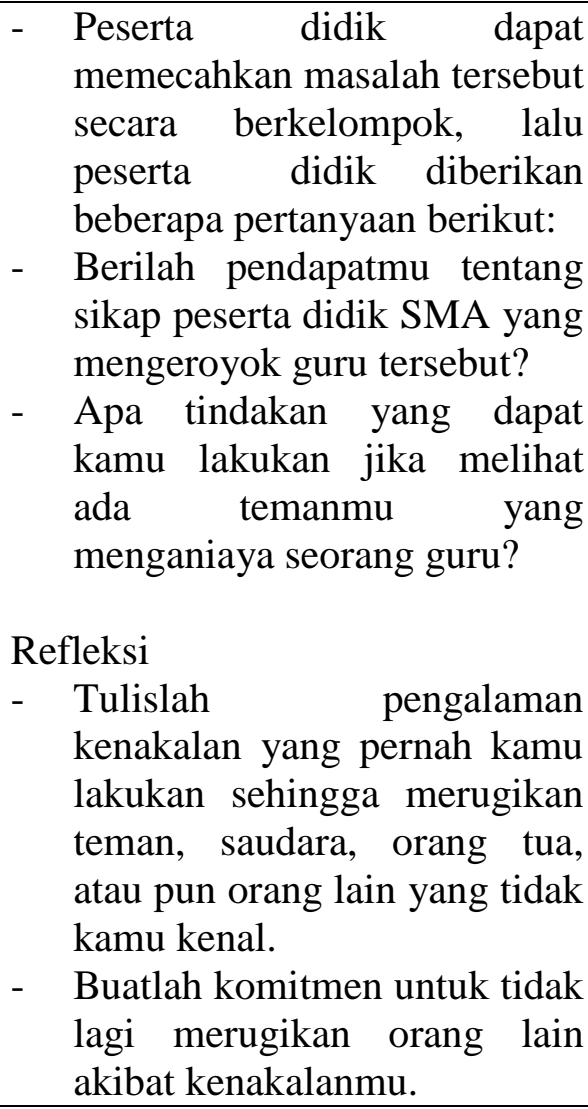 \\
\hline 3 & $\begin{array}{l}\text { Orangtuaku } \\
\text { Sahabatku } \\
\text { (Kel. 20:12) }\end{array}$ & $\begin{array}{l}\text { Contoh permasalahan ini } \\
\text { disajikan dalam bentuk } \\
\text { cerita diary seorang anak } \\
\text { kelas } 3 \text { SMP yang } \\
\text { bercerita tentang orang } \\
\text { tuanya. Di mana orang } \\
\text { tuanya selalu ada dan } \\
\text { selalu membantunya } \\
\text { dalam segala hal. } \\
\text { Ayahnya } \\
\text { pahlawan baginya dan } \\
\text { idolanya, sedangkan } \\
\text { ibunya selalu } \\
\text { membantunya setiap hari } \\
\text { mulai dari bangun tidur } \\
\text { sampai malam hari. } \\
\text { Suatu hari dia bertengkar } \\
\text { dengan ibunya dan dia } \\
\text { selalu merasa bahwa } \\
\text { ibunya sangat cerewet, } \\
\text { sangat kuno, suka } \\
\text { mengatur. }\end{array}$ & 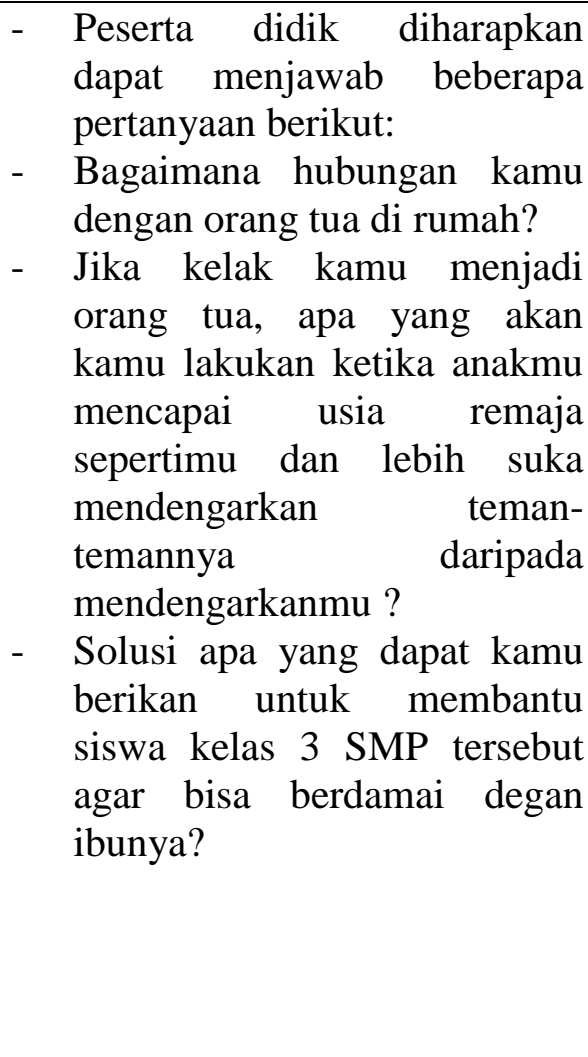 \\
\hline
\end{tabular}




\begin{tabular}{|l|l|l|l|}
\hline 4 & Apakah & Apakah Tuhan Yesus & Peserta didik membaca Kitab \\
& Tuhan Yesus & Kristus adalah mesias? & $\begin{array}{l}\text { Lukas 9:18-21 dan mencari } \\
\text { Kristus }\end{array}$ \\
& $\begin{array}{l}\text { Mesias? } \\
\text { (Luk. 9:18- }\end{array}$ & & $\begin{array}{l}\text { menyatakan Tuhan Yesus Kristus } \\
\text { adalah Mesias, menonton video }\end{array}$ \\
& & & $\begin{array}{l}\text { perdebatan tentang ke-Mesiasan } \\
\text { atau ketuhanan Yesus Kristus. }\end{array}$ \\
\hline
\end{tabular}

Tabel 1. Contoh Pembelajaran PAK di Sekolah Menggunakan Metode Problem Solving untuk siswa/murid SMP

Materi dalam tabel di atas hanyalah contoh bentuk garis besar dengan penggunaan metode problem solving pada pembelajaran PAK. Oleh karena itu, guru PAK dapat membuat materi pembelajaran sendiri atau dapat mengikuti materi pelajaran yang telah disediakan oleh sekolah. Namun guru PAK juga perlu mengingat bahwa dalam menentukan materi perlu menyesuaikan dengan tingkat usia dan kemampuan peserta didik. $^{28}$ Untuk mengetahui kemampuan dari spritual peserta didik yang sesuai dengan tingkatan usianya, para guru PAK dapat mempelajari Teori Perkembangan Iman (Stages of Faith) hasil penelitian dari karya James W. Fowler. Di mana dalam salah satu penelitian Fowler menjelaskan bahwa, ketika anak memasuki tahap usia remaja awal (13 tahun), anak sudah mulai mampu untuk memahami imannya secara lebih rasional. ${ }^{29}$

Pengimplementasian metode problem solving dalam pembelajaran PAK dilakukan sesuai pendekatan atau tahapan yang digunakan oleh guru itu sendiri. Berikut adalah

28 Sianipar et al., "Pelatihan Penyusunan Kurikulum Pendidikan Agama Kristen Remaja di HKBP Jatisampurna Bekasi."

${ }^{29}$ Yunardi Kristian Zega, "Teori Perkembangan Iman Remaja Menurut James W. Fowler dan Implikasinya Bagi Pendidikan Agama Kristen," Jurnal Pendidikan dan Kebudayaan Missio 12, no. 2 (Juli 6, 2020): 140-151, http://unikastpaulus.ac.id/jurnal/index.php/jpkm/ar ticle/view/488. pengimplementasian metode problem solving dalam pembelajaran PAK menurut tahapan Newell dan Simon, berdasarkan meteri yang tertera dalam tabel materi di atas, sebagai berikut. ${ }^{30}$

Tahap I: Orientasi masalah, peserta didik membaca Lukas 9:18-21, memahami masalah, menuliskan apa yang mereka pahami dari bacaan tersebut dan merumuskan masalahnya. Sebagai tambahan guru memutarkan video perdebatan antara orang Kristen dengan penganut agama lain tentang ketuhanan Yesus Kristus (ini sebagai masalah yang hampir sama dan perangsang bagi peserta didik dalam rangka memahami pentingnya mereka memiliki pemahaman yang benar tentang siapa Yesus). Peserta didik menuliskan langkah-langkah yang harus ditempuh dalam mencari data tentang kemesiasan Yesus Kristus dalam Alkitab dan buku-buku referensi lainnya baik yang disarankan guru atau dicari sendiri oleh peserta didik.

Tahap II: Peserta didik mendiskusikan masalah yang diberikan yaitu apakah Yesus Kristus adalah Mesias? Dalam diskusi ini, setiap peserta diberi kesempatan untuk menyampaikan pendapatnya sesuai dengan pemahaman awal mereka tentang kemesiasan Yesus. Ketika diskusi berlangsung, guru terus

\footnotetext{
30 Pramesti Wardani dan Wasitohadi, "Pengaruh Model Problem Based Learning Dan Problem Solving Terhadap Kemampuan Pemecahan Masalah Mupel IPA Kelas IV Sekolah Dasar Gugus Sembodro," JURNAL ILMIAH WAHANA PENDIDIKAN 6, no. 2 (2020): 176-184.
} 
memberi bimbingan dan arahan bagi peserta didik, terlebih saat mereka mengalami kesulitan memahami masalah yang akan dipecahkan. Dalam pembimbingan ini, guru juga dapat memberi beberapa pertanyaan yang dapat memecahkan masalah tersebut. Selain berdiskusi, peserta didik juga diarahkan untuk mencari dan membaca nubuat tentang Mesias dalam Kitab Yesaya dan kitab lainnya, membaca sumber-sumber lain terkait Yesus Kristus sebagai Mesias, menuliskan fakta-fakta tentang Yesus sebagai Mesias, mengidentifikasi dan menuliskan ciri-ciri Mesias, selanjutnya didiskusikan ulang hasil penemuan tersebut. Setelah ada kesepakatan kelompok selanjutnya ditarik simpulan yang nantinya dipresentasikan di depan kelas.

Tahap III: Peserta didik diminta untuk mempersentasikan hasil pemecahan masalah yang sudah disepakati kelompok. Selanjutnya, guru bersama peserta didik lainnya mengevaluasi hasil yang dipresentasikan. Dalam presentasi ini, peserta didik diperkenankan untuk mengajukan pertanyaan, sanggahan atau persetujuannya terhadap hasil pemecahan masalah kelompok tersebut. Dalam kesempatan ini, terjadi proses pembelajaran yang aktif, di mana setiap peserta didik memiliki kesempatan untuk menunjukkan kemampuannya dalam menyampaikan pendapat atau sanggahan. Jika terjadi perdebatan yang berkepanjangan, guru berperan sebagai penengah dan atau pengambil keputusan akhir.

Jadi, dengan adanya metode pembelajaran problem solving ini, diharapkan peserta didik dapat terlibat secara aktif. Untuk itu, guru dalam hal ini harus terus mendorong semua peserta didik ambil bagian dalam menyelesaiakan tugas-tugas sesuai pembagian yang telah disepakati. Selain itu, adanya metode pembelajaran problem solving ini juga akan memberikan semangat kepada setiap peserta didik untuk belajar karena mereka secara langsung terlibatan dalam penyelesaian masalah tersebut. Keberhasilan peserta didik dalam menyelesaikan masalah, akan memberi kebanggaan tersendiri dan mendorong mereka lebih bersemangat untuk belajar. Lebih dari pada itu, keterlibatan mereka secara langsung dalam memecahkan masalah yang diberikan membangkitkan rasa percaya diri mereka dan mereka termotivasi sehingga memiliki sikap optimis tinggi dalam menghadapi dan memecahkan masalah yang mereka temui.

\section{Kesimpulan}

Berdasarkan kajian yang dilakukan penulis dalam artikel, penulis menyimpulkan bahwa, penggunaan metode problem solving dalam pembelajaran PAK dapat meningkatkan kemampuan berfikir kritis setiap peserta didik sehingga memiliki kreatifitas dan ide-ide kreatif dalam memecahkan masalah. Penggunaan metode problem solving dalam pembelajaran PAK, mamacu peserta didik berani mengemukakan pendapat, baik melalui diskusi maupun presentasi. Keterlibatan peserta didik secara langsung, tepat dan bertanggung jawab dalam penyelesaian masalah membuat mereka antusias dalam mengikuti proses pembelajaran PAK. Keberhasilan peserta didik dalam menyelesaikan masalah juga memberi kepuasan dan kebanggaan tersendiri bagi mereka. Dengan demikian, penggunaan metode problem solving dapat meningkatkan pembelajaran PAK. 


\section{Referensi}

Asyirint, Gustaf. Langkah Cerdas Menjadi Guru sejati Berprestasi. Yogyakarta: Bahtera Buku, 2010.

Bhri, Syaiful, dan Aswan Zain. Strategi Belajar Mengajar. Jakarta: Rineka Cipta, 2002.

Darmadi, Hamid, Sulha, dan Ahmad Jamalong. Pengantar Pendidikan. Bandung: Alfabeta, 2018.

Edison, Thomas. 52 Metode Mengajar. Bandung: Kalam Hidup, 2017.

Floren, M. Reyhan. "Penerapan Metode Problem Solving Untuk Meningkatkan Hasil Belajar Siswa dalam Pembelajaran IPS di Kelas IV SDN Pojok 03 Kabupaten Tulungagung." PENA SD (Jurnal Pendidikan dan Pembelajaran Anak Sekolah Dasar) 2, no. 1 (2016): 922.

Hartanto, Suryo. Mobalean Meaning (Model Pembelajaran Berbasis Lean Manufacturing).

Yogyakarta:

Deepublish, 2020.

Khairani, Indah, dan Rini Safitri. "Penerapan Metode Pembelajaran Problem Solving Untuk Meningkatkan Hasil Belajar Peserta Didik Pada Materi Usaha Dan Energi di MAN RUKOH Banda Aceh." Jurnal Pendidikan Sains Indonesia 5, no. 2 (Februari 2, 2018): $\quad 32-41$. http://jurnal.unsyiah.ac.id/JPSI/articl e/view/9814.

Latip, Abdul. "Saatnya Tinggalkan Metode Pembelajaran Konvensional." Kompasiana. Last modified 2018. Diakses Maret 12, 2021.

https://www.kompasiana.com/altip/5 c0db2cbab12ae71c8361e04/saatnya- tinggalkan-metode-pembelajarankonvensional.

Majid, Abdul. Strategi Pembelajaran. Bandung: Remaja Rosdakarya, 2013.

Mulyasa, E. Strategi Pembelajaran PAUD. Bandung: Remaja Rosdakarya, 2017.

Rohmanurmeta, Fauzatul Ma'rufah, Arni Gemilang Harsanti, dan Heny Kusuma Widyaningrum. "Pengaruh Metode Brainstorming terhadap Motivasi dan Hasil Belajar pada Pembelajaran Tematik Integratif." Jurnal Dimensi Pendidikan dan Pembelajaran 4, no. 2 (2016): 1019.

Said, Alamsyah, dan Andi Budimanjaya. 95 Strategi Mengajar Multiple Intellegences. Jakarta: Kencana, 2015.

Sani, Ridwan abdullah. Inovasi Pembelajaran. Jakarta: Bumi Aksara, 2009.

Sanjaya, Wina. Staretegi Pembelajaran Berorientasi Standar Proses Pendidikan. Jakarta: Kencana, 2013.

Setyawan, Tatag. "Meningkatkan Prestasi Belajar Pendidikan Agama Kristen dalam Materi Menjaga dan Memelihara Alam dengan Menggunakan Model Pembelajaran Problem Solving di SMP Negeri 1 Rantau Pulung." Jurnal Ilmu Pendidikan LPMP Kalimantan Timur 11, no. 2 (2017): 23-32.

Sianipar, Desi, Stanley Rambitan, Wellem Sairwona, dan Yunardi Kristian Zega. "Pelatihan Penggunaan Metode Mengajar Remaja di Masa Pandemi Covid-19 di HKBP Resort Jatisampurna Bekasi." JURNAL ComunitÃ Servizio: Jurnal Terkait Kegiatan 
Pengabdian kepada Masyarakat, terkhusus bidang Teknologi, Kewirausahaan dan Sosial Kemasyarakatan 2, no. 2 (2020): 406-428.

Sianipar, Desi, Yunardi Kristian Zega, Luterius Nehe, dan Kristiantoro. "Pelatihan Penyusunan Kurikulum Pendidikan Agama Kristen Remaja di HKBP Jatisampurna Bekasi." JURNAL ComunitÃ Servizio: Jurnal Terkait Kegiatan Pengabdian kepada Masyarakat, terkhusus bidang Teknologi, Kewirausahaan dan Sosial Kemasyarakatan 2, no. 2 (2020): 447-457.

Simanjuntak, Junihot. Filsafat Pendidikan dan Pendidikan Kristen. Yogyakarta: ANDI, 2017.

Sudjana, Nana. Dasar-dasar Proses Belajar Mengajar. Bandung: Sinar Baru Algensindo, 2009.

Sukmadinata, Nana Syaodin, dan Erliana Syaodin. Kurikulum dan Pembelajaran Kompetensi. Bandung: Refika Aditama, 2014.

Supriyadi, Supriyadi. "Community of Practitioners: Solusi Alternatif Berbagi Pengetahuan antar Pustakawan." Lentera Pustaka: Jurnal Kajian Ilmu Perpustakaan, Informasi dan Kearsipan 2, no. 2 (Februari 23, 2017): 83. https://ejournal.undip.ac.id/index.ph p/lpustaka/article/view/13476.

Susanto, Herry Agus. Pemahaman Pemecahan Masalah Berdasarkan Gaya Kognitif. Yogyakarta: Deepublish, 2015.

Wardani, Pramesti, dan Wasitohadi. "Pengaruh Model Problem Based Learning Dan Problem Solving Terhadap Kemampuan Pemecahan
Masalah Mupel IPA Kelas IV Sekolah Dasar Gugus Sembodro." JURNAL ILMIAH WAHANA PENDIDIKAN 6, no. 2 (2020): 176184.

Wartini, Ii, Hilman Mangkuwibawa, dan Cecep Anwar. "Penerapan Metode Problem Solving Untuk Meningkatkan Pemahaman Matematika." al-Aulad: Journal of Islamic Primary Education 1, no. 2 (November 6, 2018). http://journal.uinsgd.ac.id/index.php/ al-aulad/article/view/3519.

Zega, Yunardi Kristian. "Teori Perkembangan Iman Remaja Menurut James W. Fowler dan Implikasinya Bagi Pendidikan Agama Kristen.” Jurnal Pendidikan dan Kebudayaan Missio 12, no. 2 (Juli 6, 2020): 140-151. http://unikastpaulus.ac.id/jurnal/inde x.php/jpkm/article/view/488. 